\title{
Trade War - A Threat to Multilateral World Trading System under WTO: Recent Trends
}

\author{
Anil Bhuimali ${ }^{1}$ and Debasish Chakraborty ${ }^{2 *}$ \\ ${ }^{1}$ Vice Chancellor-Raiganj University, Raiganj, West Bengal, India \\ ${ }^{2}$ Department of Economics, University of North Bengal, West Bengal, India \\ *Corresponding author: chakrabortydebasish789@gmail.com
}

\begin{abstract}
In this paper, we wanted to point out how Trade war begins with nationalist rhetoric and old protectionist slogans to gain National Welfare. We discussed how United States dominated the world trade and initiated most of the Trade wars. We also understood from our study that such type of trade wars are basically damaging to global trading system by harming small countries mostly and bringing no welfare gains for the US. We discussed how US -China trade wars took place and explained these trade wars are the results of domestic protectionist measures of these countries. The US govt. implements high tariff which damages Terms of Trade, Friendly Cooperation between trading nations, and initiates retaliations among trading partners with Nash Equilibrium. At last we can say that from these types of trade conflicts the US govt. though adds sectoral gains in the value added but ultimately gains no welfare for the country itself. In case of US-China trade wars the loss for China are comparatively smaller as compare to other nations. After beginning of any trade wars there exits free riders that can damage many areas of trade and TOT deteriorations can even depends on how retaliations from opposite countries takes place.
\end{abstract}

Keywords: Trade wars, USA, China, Welfare, Protectionism

Trade war unlike direct war is an economical war between countries engage in world trade. The core reason behind trade wars are narrow financial interest of nations and protectionist behaviour of them. The instruments used by nations in trade wars are Tariffs, Quotas, Anti dumping orders, and many other trade barriers. The tendency is seen to get self sufficiency in production \& trade and more stress on unilateral or bilateral trade in place of multilateral universal dependency on trade and tariff. Some time for domestic protectionist measure countries are seen to be using tools like hiking subsidies or raising tariff, as a result of which other countries retaliates in the same manner and in this way it ends with vigorous trade wars. Trade wars are damaging for domestic output $\&$ employment, for example we can 
site Great depression in 1930s which was the consequence of trade protectionism. Mostly trade wars begin with either domestic protectionism which occurred sometimes by political pressure by domestic political parties to raise tariffs to boost domestic output \& employment and imperialist tendencies for market expansion for domestically produced goods. Sometimes countries fail to understand the benefits of free \& multilateral trade before engaging into trade wars. Trade war creates the bases of suspicion and mistrust among nations which eliminates the Idea of multilateral trade or free trade.

\section{Objective of the Study}

Our objective of the study is to find out (1) if trade wars take place among many types of countries, which type of countries tend to loose from trade war? Are they Small countries or large countries? (2) Is it the big economies which are going to gain from Trade wars? (3) Role of the United States of America to Trade Wars.

\section{Research Methodology}

The present study is based on secondary data. The secondary has been collected and compiled from books related topics, magazines, reputed journals, research paper, news paper, internet sources like www.wto. org. Data are obtained from the WTO, UN data sources, various national \& International journal on USChina trade relationship, Books both online \& offline, several research work done by scholars on the relevant topic. We study various scenarios of trade wars initiated by non cooperative action implemented by the US government. We discussed how countries are targeted by the additional tariff implemented by the United States. We model a US trade policy change consisting of an additional tariff of 35 percentage points applied to all goods except energy goods coming from either China. Then we discussed the type of retaliation implemented by the US trading partner(s).

\section{Welfare gains from trade}

Welfare gains from trade are a very important topic to be discussed internationally. If we see trade history of nations we will notice national wefare has been always gained positively each time nations engaged in bilateral or multilateral trade agreements. Empirically it is found that since 2000 many countries in the world has dabbled their GDP after engaging in multinational trade under WTO. According to I.M.F. the ratio of global imports to global GDP increased from $20.4 \%$ in 1997 to $34.5 \%$ in 2016 , implying a gross decline in the share of domestic expenditure of $18 \%$ and a corresponding welfare increase on the order of $2.6 \%-7.0 \%$ of global GDP. In other words, were one to roll back the gains from trade over that period, it would be tantamount to erasing roughly one to two years of global GDP growth. In the TRAINS data, the average country had $17 \%$ more varieties (defined crudely as the number of productpartner trade links) in 2014 relative to 2005 . So international trade not only gives boost to domestic GDP but also allows countries to diversify trade in different commodities and services which help countries revive from recession and generate numerous Jobs for factors and mobility of factors becomes better. In this way welfare gain from trade would be visible if free $\&$ fair trade can take place among a nations. 


\section{Literature Review}

If we start looking at trade war history from early $20^{\text {th }}$ century, particularly in the time of great depression we will notice that there was retaliatory trade war history took place in the early 1930s. USA took the first move mostly; like in June 1930, total imports of US fell down by about $40 \%$ as a result of tariff imposing on European counterpart. At the same time USAs share of world also reduced from $16 \%$ to $11 \%$ in between 1930 to 1935, as a result of retaliatory measures taken by European nations and others in the world. This led drop in USAs output, income and employment leading to Stagflation and Great depression in the 1930s. Economist Irwin showed in 1998 that at the time of Great Depression USA lost about $0.3 \%$ to $1.6 \%$ of its total gross national output. And this is termed as efficiency loss due to trade war. Let us now discuss some of the theoretical aspects related to Trade Wars.

Johnson (1953): under neoclassical framework and with perfect competition Johnson in 1953 showed that when Trade Wars take place larger countries tend to gain from it and smaller countries tend to loose from it. According to Johnson a big country's welfare is better under trade war situation under Nash Equilibrium but small country's welfare is reduced. ${ }^{[9]}$

Grossman and Helpman (1995): According to Grossman and Helpman most nations engage in trade war not because to gain Domestic welfare but the Leaders of these nations do so mostly to gain their political campaign contributions by special interest groups of those nations. ${ }^{[6]}$

Riezman( 1982); and Dixit (1987), Bagwell and Staiger (1999): According to these economists the countries that engage in trade wars later they sit together and forms Cooperative Equilibrium or Tariff Equilibrium of trade among themselves in order to achieve business goals and trade welfare and avoid further trade Wars.

Bagwell and Staiger (2002): In their theory Bagwell \& Staiger have shown how nations manipulate Terms of Trade through trade restrictions to gain welfare at the expense of their trading partners. At the same time they have express the significance of WTO as a multilateral body to eliminate the pressure of Protectionism and trade Wars among nations. ${ }^{[2]}$

Bouët and Laborde (2010): In their study also Bouët and Laborde looked at the scenario of a multilateral trade war in which the tariffs applied by major economies between 2009 and 2014 increase to the currently bound tariff rates. These authors found that under this scenario, world trade decreases by 7.7 percent and world welfare drops by US $\$ 353$ billion.

Ossa (2014): Ossa found that all countries would be in a worse situation if they implement optimal tariff of $63.4 \%$ and if they do so they will loss $2.9 \%$ under Nash Equilibrium. He proposed a multi-country, multi-industry general equilibrium model of international trade in which governments impose import duties in order to manipulate the terms of trade (the optimum tariff argument), shift profits away from other countries (the strategic trade policy argument), and protect politically influential industries (the political economy argument). ${ }^{[13]}$

If we see the history we will notice that there have been a number of trade wars in the last 100 years. For example the:

1. Boston Tea Party (1773) was an example of unfair trade measure imposed on USA and the resistance by USA on that which was a catalyst for the American Revolution later on. 
2. In 1830s the Qing Dynasty of China got into trade war with the British Merchants, which is famously known as Opium War and ended with the destruction of Qing Dynasty.

3. The Smoot-Hawley TariffAct, 1930s: In 1930s USA put tariff(Famously known as Smott-Hawley Tariff act) in a huge manner on imports (particularly from European nations) in order to safeguard domestic factories and boost up productions. But later on this US move ended in Great Depression of 1930s as a consequence of European retaliation to US goods. This trade war ultimately escalated into real war (World War II), and the economic devastation due the war is well-known to everyone. After the Second World War trade negotiation again started among nations and General Agreement On Trade \& Tariff came into existence as a measure to avoid the menace of trade war again.

4. Chicken War (1963): The famous Chicken war between the US and French-German led European countries occurred in early 1960s where USA put a ban on US imports of Chicken from Europe and for that as a retaliatory action France \& Germany raised tariff on Us made Trucks and Liquor.

5. The Pasta War and Trade War with Japan in 80s: The Ronald Reagan govt in USA put tariff on Europe to stop imports of Pasta and as retaliation European nations stopped importing US walnuts and Citrus fruits. This dispute ended in early 1987 after an agreement between the nations. This Ronald Reagan even raised tariff on Japan (1981) made Vehicles import as the US was flooding by Japan made cars in 1980s. At this time Japan retaliated by reducing its Imports of Semiconductors, Motorcycles and Electronics from USA.,

6. Trade War on Woods (1982): In the early 1980s Canada and the USA engaged in trade war of Woods, particularly Soft wood lumber imports from Canada.

7. Latin America and European Trade war on Banana (1993): In the early 1990s the European nations stopped import of Latin America produced banana, as result of which the Latin American companies filed complaints to the WTO for this unfair measure taken by the European nations.

8. Tariff Introduced by USA on Steel Import (2002): To revive the steel industry from recession and create job the US govt. led by George W. Bush increased tariff rates on still imports from European nations and as a result of which retaliatory actions came from Europe as increased tax on Orange import from USA. In this whole process none of the countries benefitted, on the contrary Jobs in the US got declined after stabilising for some time.

From the above review of literature about Trade Wars we can say that it is prejudicial and nationalist rhetorical for countries in the world to engage in trade war for domestic benefit or Welfare gain. For both multilateral and bilateral trade, according to Jhonson both the countries either loose or the large country benefits and small country loose after trade war is complete, and ultimately welfare is decreased.

\section{Trade War (A case study of USA \& China in recent time)}

USA (United States Of America) and PRC (Peoples Republic of China) being the world two largest economies, where US GDP is \$18.56 trillion nominal with a population of 324 million in 2016 and China's \$11.4 trillion nominal with a population of 1379 million are mostly prone to trade deficits. USA is world's largest economy with highest trade deficit. Though China is not suffering from trade deficit as US is suffering. Both China and the United States are members of the multilateral organisation called WTO (where USA is the founding member from $1^{\text {st }}$ jan. 1995 and China became member from 2001). Here the noticeable thing is that though US has its trade deficit with many countries of the world but it 
has its largest trade deficit with China. Since from last decade most US manufacturing firms are suffering from lack of demand, output \& employment, along with this it has been facing anti incumbency with nationalist rhetorical slogans So, the Country has to do something in this regard to generate domestic employment output and demand. The new US Republican president Donald J. Trump after coming to his white house office started giving emphasis on trade restriction and protectionary measures to foreign imports, specifically from China and EU. The US President Donald has started protectionist campaign, in order to bring manufacturing jobs back to the United States from outsourcing nations like China and India. In 2018, the US President Donald Trump has initiated trade war like situation by announcing of raising tariff on imported goods from China up to $\$ 500$ billion and 25\% tariff hike on Steel imports from EU, even he threatened about the possible US withdrawal of membership from WTO. (WTO with 164 members is the only multilateral trade organisation which guarantees free \& fair impartial international trade). Trump said they are mainly concerned with the Chinese exports to USA of manufactured \& robotic goods, Electronic goods. From the Chinese side the ministry of Commerce has expressed their deep concern of this sudden US move toward unwanted protectionist measures and said that China will no longer waste time to retaliate(The ministry has said it will raise tariff on US agricultural export to china and initially it will be $\$ 25$ billion).

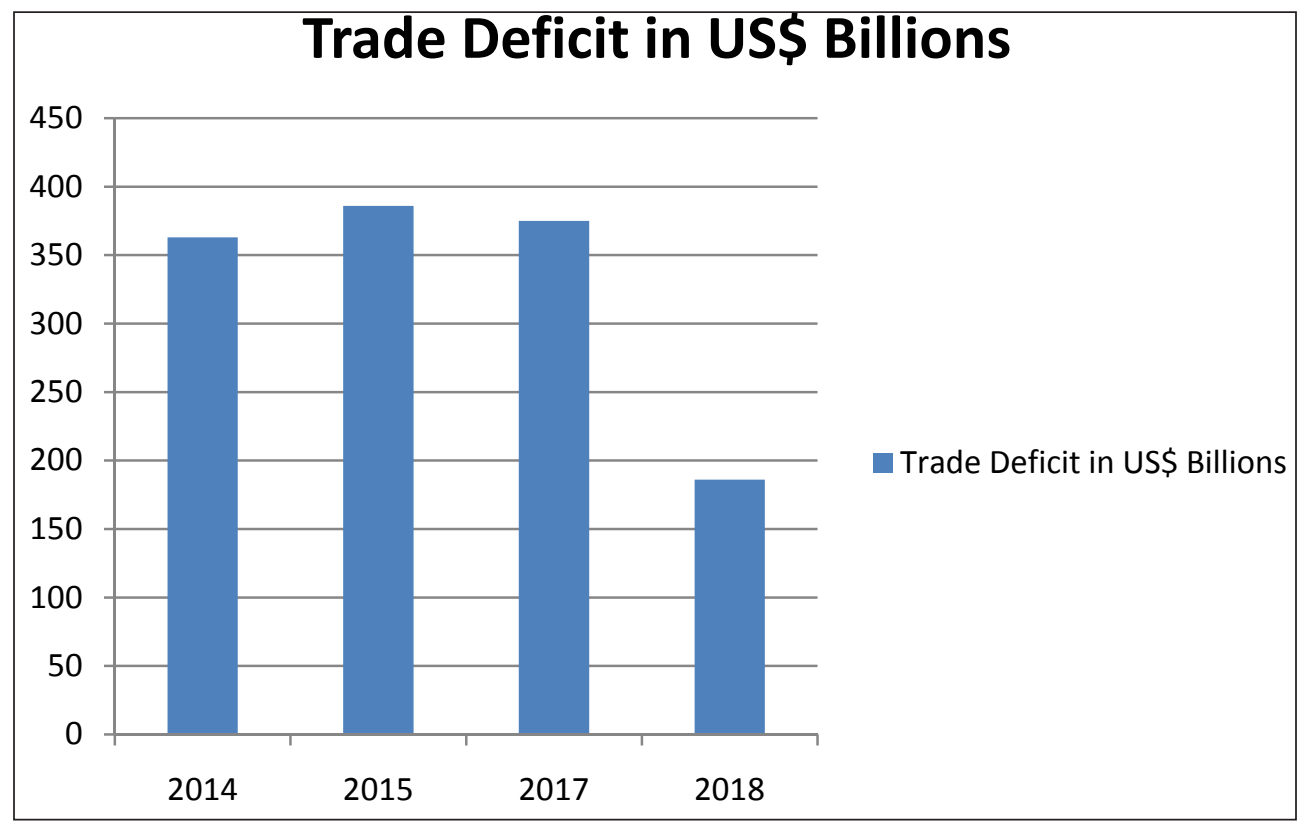

Fig. 1: Current US Trade Deficits with China (In US\$ Billions)

Source: The UN Comtrade Data base (UN 2017-18)

From the tables it is clear that why the US trade deficits are rising sky high with China day by day. From latest data we can see that the US imports from China in 2017 included computers and electronic products (34.8 percent), electrical equipment, appliances and components ( 8.8 percent), and other miscellaneous manufactured goods ( 8.5 percent), where US exports to China Were transportation equipment (22 percent of total exports in value), agricultural products (14.9 percent), and computers and electronic products 
(14.8 percent). According to the trade value added (TIVA) data base of WTO and OECD countries Both US and China's Global Participation Index are very low as compare to the Developing nations, which shows both US and China's participation in the Global trade are characterised by backward participation or vertical specialisation. This shows both the countries have low forward participation in GVC (Global Value Chain) as both the nations import foreign inputs to produce final goods and services to export.

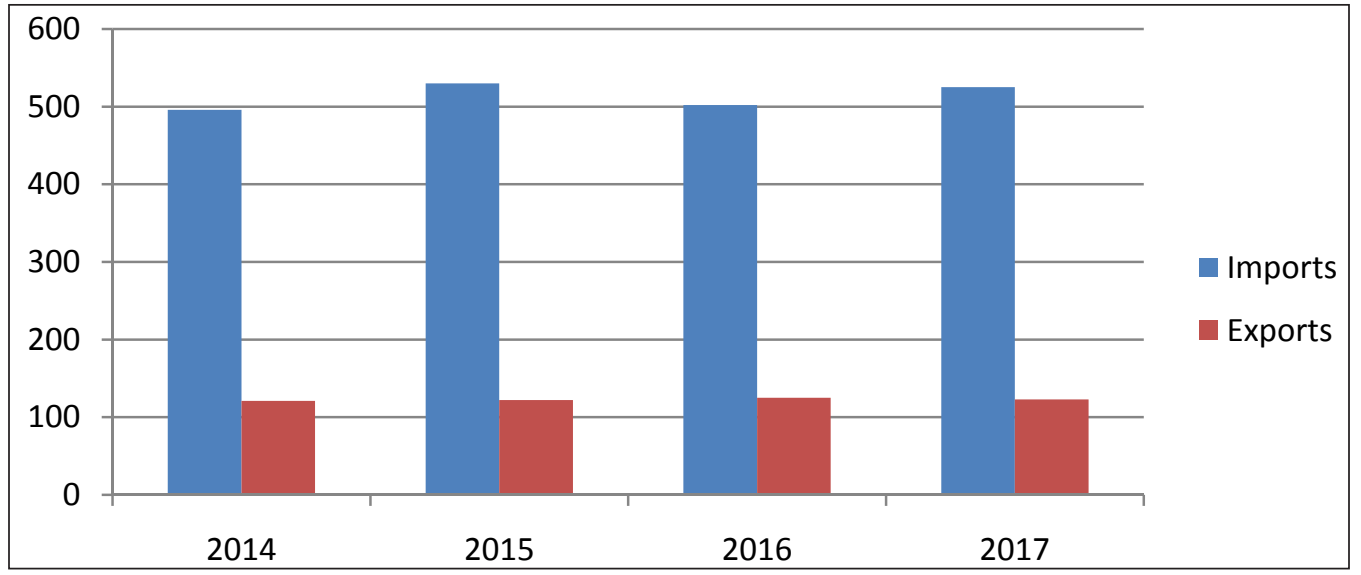

Fig. 2: US Imports \& Exports of Goods with China (Estimated in US\$ Billions)

Source: The International Trade Administration, US Department of Commerce (2017).

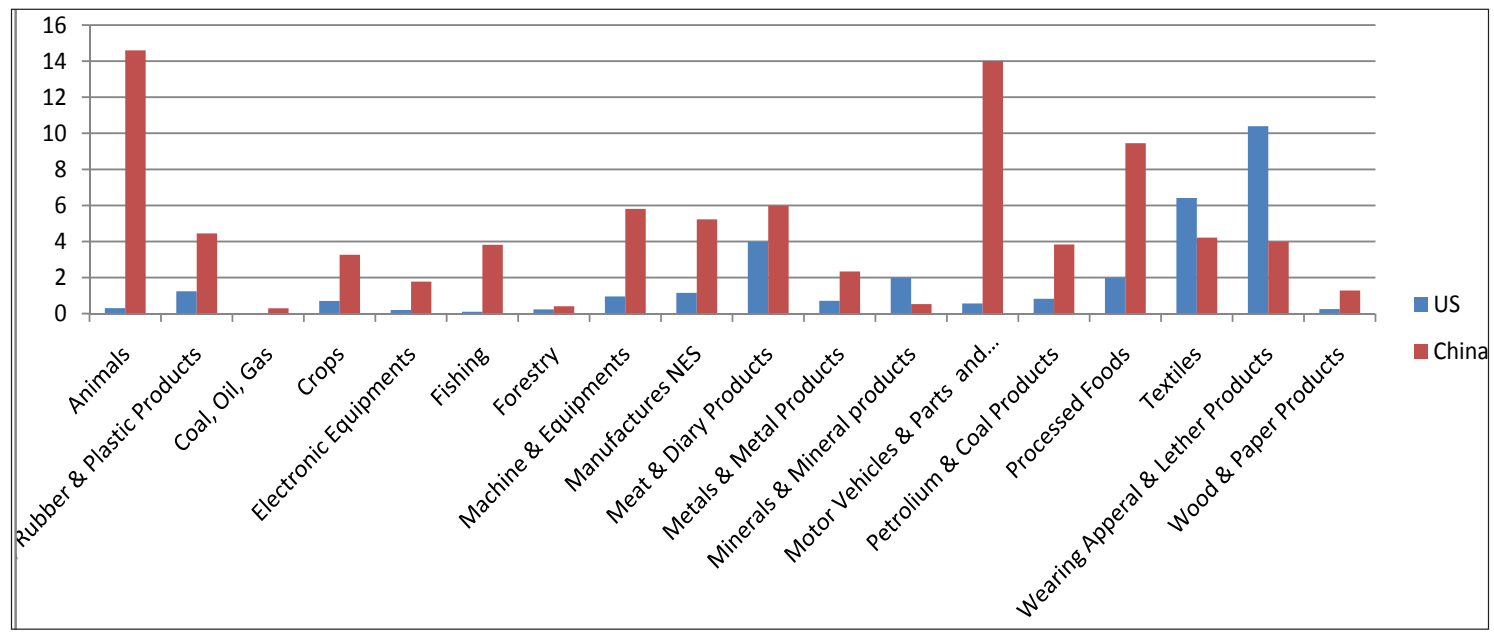

Fig. 3: The level of Protection of Goods in different sectors of US \& China (In Percentage)

Source: GTAP 9 (GTAP 2017) and MIRAGRODEP (AGRODEP 2013) databases.

Fig. 3 shows the level of protection in China and the United States by sector. This is the sectoral disaggregation used here. US protection is seen to be low in all sectors except wearing apparel and leather products. Average protection by sector varies much more in China (with a peak in motor vehicles and parts, transportation equipment, and animals). 
Table 1: The Scenario of the amount of Tariff Changes Implement in US-China Trade Relations (in $\%$ points)

\begin{tabular}{llcccc}
\hline & & \multicolumn{2}{c}{ Short Term Closure } & \multicolumn{2}{c}{ Long Term Closure } \\
\cline { 3 - 5 } & & United States & China & United States & China \\
\hline 1. & US unilateral Tariff & 35.0 & NA & 35.0 & NA \\
2. & 35\% Tariff retaliation & 35.0 & 35.0 & 35.0 & 35.0 \\
3. & Tariff revenue retaliation & 35.0 & 59.9 & 35.0 & 59.7 \\
4. & Terms Of Trade Retaliation & 35.0 & 42.9 & 35.0 & 38.5 \\
5. & Optimal Welfare Retaliation & 35.0 & 4.1 & 35.0 & 3.7 \\
6. & Nash Equilibrium & 7.0 & 3.6 & 7.0 & 3.1 \\
\hline
\end{tabular}

Source: WTO data 2016.

The above table shows that China faces a severe loss due to US imposition of a 35-percentage-point increase in import duties on Chinese products. China has to impose a relatively high amount of import tariff on US to maintain its initial TOT. China's trade flow to US is much bigger than what the US trade flow to China itself, so Chinese Govt's retaliation should be much bigger. But at the end both China and the US do not maximise trade welfare gain after engaging into trade war. One thing is revealed to be interesting in our study is that US optimal tariffs against China are smaller and elasticity of Import are higher than other countries like Mexico and others Developing nations.

\section{Impacts of trade wars on International trade}

When trade wars occur between China and the US the peripheral destruction due to trade war becomes much larger than impact on total exports by both countries. Both the countries suffer a lot with other developing nations in the world as the size of the two economies involved and their involvement in regional trade on both sides of the Pacific, side effects on third parties are much larger than trade with the developing nation states. Trade war brings trade deflection between the two belligerents is more transparent in the US-China trade war.

Table 2: The worlds Value chain participation Index 2011

\begin{tabular}{cccc}
\hline & China & Developing Countries & Developed Countries \\
\hline Total Participation & 47.7 & 48.6 & 48 \\
Forward Participation & 15.6 & 23.1 & 24.2 \\
Backward Participation & 32.1 & 25.5 & 23.8 \\
\hline
\end{tabular}

Source: WTO Data (2016).

Let us now assess countries' level of protection. Fig. 4 shows the average level of protection by country or region included in this study for all goods and all partners. Because we weigh tariffs by bilateral trade, this indicator rather underestimates the average protection. However, it illustrates today's low level of average protection, particularly in the United States. 
Table 3: US-China scenarios showing Share and rate of variation in value-added, in volume and by sector (percentage points)

\begin{tabular}{ccccccccc}
\hline & \multicolumn{2}{c}{$\begin{array}{c}\text { Share of value- } \\
\text { added }\end{array}$} & \multicolumn{2}{c}{$\begin{array}{c}\text { China_ } \\
\text { Unilateral_LT }\end{array}$} & $\begin{array}{c}\text { China_Revenue } \\
\text { Retaliation_LT }\end{array}$ & China_Nash_LT \\
\cline { 2 - 9 } & China & US & China & US & China & US & China & US \\
\hline Other animal products & 2.84 & 0.23 & -0.3 & -0.2 & -0.5 & -1.4 & -0.1 & -0.3 \\
Chemical, rubber, plastic products & 4.32 & 3.05 & 0.2 & -0.1 & 0.9 & -0.9 & 0.2 & -0.3 \\
Coal, oil, gas & 2.51 & 1.78 & 2.0 & -1.0 & 1.2 & 0.7 & 0.6 & -0.1 \\
Crops & 5.29 & 0.96 & 0.3 & -1.0 & 2.1 & -6.6 & 0.3 & -1.1 \\
& 2.26 & 0.54 & -6.3 & 4.6 & -7.8 & 4.7 & -2.8 & 1.3 \\
Fishing & 1.09 & 0.04 & 0.0 & 0.0 & 0.0 & -1.0 & 0.0 & -0.1 \\
Forestry & 0.66 & 0.08 & -0.4 & 0.4 & 0.9 & -4.6 & 0.1 & -0.7 \\
Electronic Equipments & 5.53 & 3.87 & 0.4 & -1.0 & 0.6 & -1.3 & 0.1 & -0.6 \\
Machinery and equipment & 1.79 & 0.36 & -4.0 & 5.6 & -4.6 & 7.2 & -1.5 & 2.0 \\
Manufactured Products & 0.30 & 0.55 & 0.3 & -0.4 & 0.7 & -0.8 & 0.3 & -0.3 \\
Meat \& Diary Products & 4.79 & 2.08 & 0.7 & -0.2 & 0.9 & -0.4 & 0.2 & -0.3 \\
Metals and metal products & 4.29 & 0.66 & 1.1 & -0.4 & 0.6 & 0.4 & 0.3 & -0.1 \\
& 0.35 & 0.10 & -0.1 & 0.5 & 0.2 & 0.3 & 0.0 & 0.2 \\
Minerals and mineral products & 2.17 & 1.38 & -0.3 & -0.1 & -0.9 & -0.3 & -0.1 & -0.1 \\
Petroleum \& Coal Products & 1.30 & 0.46 & -0.9 & 5.2 & -2.9 & 6.1 & -0.5 & 1.8 \\
Processed Foods & 2.45 & 1.76 & 1.0 & -1.8 & 1.8 & -2.3 & 0.5 & -0.8 \\
Textiles & 1.32 & 0.29 & -2.4 & -6.3 & -3.9 & 7.5 & -1.0 & 2.2 \\
Transportation Equipments & 1.56 & 2.43 & -1.8 & 1.5 & -1.2 & 0.7 & -0.5 & 0.3 \\
Wearing app. and leather prod. & 1.32 & 0.29 & -2.4 & 6.3 & -39 & 7.5 & -10 & 2.2 \\
Wood and paper products & 1.56 & 2.43 & -1.8 & 1.5 & -12 & 0.7 & -0.5 & 0.3 \\
\hline
\end{tabular}

Source: WTO Data (2016).

We can see from the above that after imposition of 35\% of import tariff on many Chinese goods by the US, several sectors in China has been affected including the Electronic equipment sector (represents 2.3 percent of total value-added and is reduced in volume by 6.3 percent), the sectors of wearing apparel and leather products, wood and paper products and nondurable manufactured goods. This may increase domestic production activity but these are small sectors in the US with limited comparative advantage globally. At the same time the US has to face Chinese retaliation in the agricultural export to China by the US (as China is one of the biggest importer of US produced food crops \& forestry product.) and in this way domestic net welfare gain after trade war is minimised in the US.

When any Govt. imposes high tariff on imports of goods from foraign countries, it indirectly affects domestic price level and creates inflation at home because demand for domestically produced good becomes high. As a result of it domestic purchasing power gets reduced and there by demand, output \& employment also. It also affects the prices of domestic intermediate goods and competitiveness along with value chain. This negatively affects the whole economic activity along with prices $\&$ demand of productive factors. Though there may be some sectors in the economy which could be affected positively 
and demand for factors would remain high for those areas even after the trade war shock also. So the final effect of trade wars should be evaluated after considering the effects of all kind of shocks in all areas.

Table 4: The variation in real wage rate of labour in USA and China (A percentage point comparison)

\begin{tabular}{|c|c|c|c|c|c|c|}
\hline & 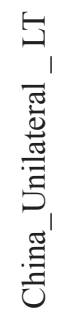 & 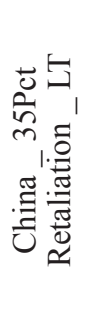 & 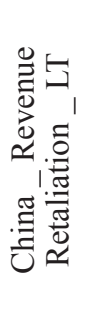 & 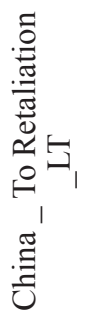 & 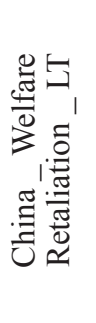 & 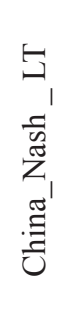 \\
\hline \multicolumn{7}{|l|}{ Changes in the US real rate of return for: } \\
\hline Skilled Workers & -0.2 & -0.3 & -0.4 & -0.3 & -0.3 & -0.1 \\
\hline Unskilled Workers (Primary Sectors) & -0.9 & -1.0 & -1.0 & -1.0 & -0.9 & -0.4 \\
\hline Unskilled workers - non-primary sectors & 0.2 & -0.3 & -0.3 & -0.3 & -0.2 & -0.1 \\
\hline Capital & -0.2 & -0.4 & -0.4 & -0.4 & -0.3 & -0.1 \\
\hline Land & -1.2 & -5.5 & -6.5 & -5.7 & -1.9 & -1.1 \\
\hline \multicolumn{7}{|l|}{ Changes in the China real rate of return for: } \\
\hline Skilled workers & -0.5 & -0.9 & -1.0 & -0.9 & -0.5 & -0.2 \\
\hline Unskilled workers (Primary Sectors) & -0.1 & 0.5 & 0.7 & 0.5 & 0.2 & 0.1 \\
\hline Unskilled workers - non-primary sectors & -0.7 & -1.1 & -1.2 & -1.1 & -0.8 & -0.3 \\
\hline Capital & -0.4 & -0.7 & -0.8 & -0.8 & -0.5 & -0.2 \\
\hline Land & 0.3 & 1.9 & 2.4 & 2.0 & 0.5 & 0.4 \\
\hline
\end{tabular}

Source: WTO data (2016).

\section{Macro Economic Impact of Trade War on USA \& China}

From the above we can understand that when USA imposes high tariff on Chinese imports or acts as a unilateral protectionist, the Macroeconomic effect by this on China is visible in two ways. For example firstly the trade war shock affects negatively on Chinese export sector as a result of this, demand for factors in this sector gets reduced and there by real remuneration also gets reduced. But at the same time as the prices of these export goods declines the real remuneration to the factors rises by this. But when china starts retaliation, the domestic prices of the foreign imports gets high due to the increased demand for factors of production domestically. This poses negative impact on the Economy. For example when USA imposed tariff unilaterally on China the Consumer Price Index fell $2.55 \%$ which was quite good but as China retaliated by imposing tariff on US exports to China the domestic prices of factors got high and the Consumers Price Index fell only by $0.42 \%$. It is visible in the long term revenue retaliation by China on US. From the above table we can see that under unilateral trade war initiated by the US, no farm owners in USA have been benefitted along with factors of production, Skilled \& Unskilled labourers also as real remuneration of all productive factors is someway damaged by this act of US government because the retaliation from China severely damaged the agricultural trade of the United States. 


\section{CONCLUSION \& POLICY RECOMMENDATION}

Our objective in the above study was to identify \& evaluate the short term \& long term trade \& economic effect on countries by trade wars and the repetitive role of the US Governments in starting trade wars by taking unilateral protectionist measures (particularly to China in recent times). What we find is this trade wars initiated by the US has always been generated from politically made nationalistic rhetoric's in order to curb the domestic political anti incumbency toward Govts for their less effective policies in generating output $\&$ employment. But the result of this trade wars has always been damaging to both in gaining domestic welfare \& internationally free \& fair trade environments. It is visible that some Sectors of US economy may benefit out of this trade war (textiles, wearing apparel and leather products, electronic equipment, and so on) but many sectors will suffer as a result of retaliatory measures by China (chemical, rubber, and plastic products; crops; meat and dairy products; motor vehicles and parts; and transportation equipment) along with this trade war with China may also hurt US skilled \& Unskilled workers in agricultural \& industrial sector. One important finding of our study is that the emergence of Free Riders as a consequence of trade wars. The free Riders effect positively to many countries or areas of trade when trade wars is going on. For example when the US-China trade war takes place both the countries engage in trade retaliation. At that time many other countries come to enjoy elevated demand from US or China (for example we can cite the CAFTA comes forward to enjoy artificially created demand for goods which becomes almost banned from China after imposing US tariff on them). As a consequence of trade wars global welfare decreases systematically. For policy recommendation to face trade wars we can say that as unilateral effort by the US to protect domestic production has damaged $0.7 \%$ of Chinese export to USA so partners of USA should remain alert to US trade sanctions and prepare domestic and international wide range of instruments to cope with these type of situation to minimise harm to domestic industries and at the same time find new ways to make international trade more friendly, multilateral and justifiable. Other than this as China has become the second largest economy in the world so it has immense retaliatory power to any trade banned to its exports. It can manipulate the supply of rare earth material to US, or it can ban many US products which are essentially demanded in China only. China can retaliate through it capital \& currency markets also. These type of instruments China can use to pressure the US Govt. to stop further escalation of trade wars and peace and harmony could be retained in international arena.

Lastly we can say that, trade wars are immensely harmful for the world economy and free \& fair trade. As net savings of any economy gets declined, the current account deficit comes in, so if any country thinks trade protectionism is the only right way to reduce current account deficit then it is wrong. To solve trade disputes we must have a multilateral international trade regulatory body which will maintain free $\&$ fair trade among nations, but if bilateral trade wars take place again and again no trade disputes can be solved as ultimately there will be no legitimacy of this multilateral institution to remain in the world trade scenario. The US govt. should also obey the multateral institutions like WTO, and if it feels that any country is either copying its products or violating intellectual rights or implementing unfair trade practices the WTO is the right place to raise these issues and find solution multilaterally.

\section{REFERENCES}

1. Anderson, K. 1994. "Multilateral Trade Negotiations, European Integration, and Farm Policy”, Economic Policy, 9(18): 13-52. 
2. Bagwell, K. and Staiger, R.W. 1999. “An Economic Theory of GATT”, American Economic Review 89(1): 215-248.

3. Bhagwati, J. 1994. "Regionalism and Multilateralism: An Overview." In New Dimensions in Regional Integration, J. de Melo and A. Panagariya (Eds.). Cambridge: Cambridge University Press.

4. Barboza, David 2007. From Shanghai, Tremors Heard around the World, in: New York Times, 28 February, online: (8 October 2007).

5. Fajgelbaum, P.D. and Khandelwal, A.K. 2016. "Measuring the Unequal Gains from Trade", Quarterly Journal of Economics, 131(3): 1113-1180.

6. Grossman, G.M. and Helpman, E. 1995. "Trade Wars and Trade Talks", Journal of Political Economy, 103(4): 675-708.

7. Grossman, G.M. and Helpman, E. 1995. "Trade Wars and Trade Talks.” Journal of Political Economy, 103(4): 675-708.

8. International Trade Administration, US Department of Commerce. 2017. Trade Statistics databases. Accessed on November 2016. www.trade.gov/mas/ian/tradestatistics/index.asp.

9. Johnson, H.G. 1953. "Optimum Tariffs and Retaliation.” Review of Economic Studies, 21(2): 142-153.

10. Karen, Tony 2001. Bush China Policy Defaults to Engagement, in: Time, 31 July, online: (7 January 2008).

11. Kennan, J. and Riezman, R. 1988. “Do Big Countries Win Tariff Wars?” International Economic Review, 29(1): 81-85.

12. Moore, M. Agriculture's State in WTO Trade Negotiations. [Online] Available, http://www.wto.org Pakistan Journal of Commerce and Social Sciences Vol.2 200966 Mustafa, U., Malik, W. and Sharif, M. (2005). Globalization and Its Implications for Agriculture, Food Security and Poverty

13. Ossa, R. 2014. “Trade Wars and Trade Talks with Data.” American Economic Review, 104(12): 4104-4146.

14. United Nations. 2017. UN Comtrade Database. Accessed on November 24, 2016. https://comtrade.un.org/.

15. United Nations. Member States of the United Nations. http://www.un.org/en/members/ [accessed 3/27/14]

16. WTO Secretariat. 2011. World Trade Report 2011: The WTO and Preferential Trade Agreements: From Co-existence to Coherence, Geneva: World Trade Organization.

17. WTO. 2013c. "Text of the 'July package' — the General Council's post-Cancun decision”.

18. WTO. 2013a. “Trade Policy Reviews.” http://www.wto.org/english/tratop_e/tpr_e/tpr_e.htm.

19. WTO International Trade Statistics, 2008 highlights World trade developments Yearbook of International Trade Statistics, Department of International Economic and social affairs, statistical office, United Nations. 
